\title{
PENGARUH LAYANAN PENGUASAAN KONTEN DENGAN TEKNIK MODELLING UNTUK MEMINIMALISIR KONSEP DIRI NEGATIF SISWA SMP NASRANI 5 MEDAN KELAS VII TAHUN AJARAN 2017/2018
}

\author{
Tenty Laonma Silaban \\ Dra. Zuraida Lubis, M.Pd.Kons \\ Program Studi BK FIP Universitas Negeri Medan
}

\begin{abstract}
Abstrak
Penelitian ini bertujuan untuk mengetahui pengaruh layanan penguasaan konten dengan teknik modelling untuk meminimalisir konsep diri negatif siswa SMP Nasrani 5 Medan Kelas VII Tahun Ajaran 2017/2018. Metode yang digunakan dalam penelitian ini adalah metode kuantitatif. Jenis penelitian ini adalah eksperimen semu denganpre-test - post-test group design. Penelitian ini dilaksanakan pada bulan Maret s/d Mei 2018.Populasi dalam penelitian ini adalah seluruh siswa kelas VII-C.Sampel dalam penelitian ini adalah sebanyak 10 orang siswa kelas VII-C yang memiliki skor terendah yang telah dibagi angket konsep diri negatif dan akan diberi layanan penguasaan konten dengan teknik modelling. Kemudian data dianalisis menggunakan uji wilcoxonuntuk melihat apakah ada pengaruh signifikan pemberian penguasaan konten dengan teknik modelling terhadap meminimalisir konsep diri negatif pada siswa. Hal ini dapat diperoleh hasil perhitungan dengan skor testawal (pre-test) pada kelompok eksperimen diperoleh rata-rata $=98,8$, standar deviasi $=12,479$ sedangkan skor $($ post-test $)$ diperoleh - rata $=159,4$, standar deviasi $=532,259$. Hal ini dapat dilihat dari hasil uji wilcoxon yang menunjukkan bahwa pada uji jenjang wilcoxon diperoleh $\mathrm{J}_{\text {hitung }}=15$ sedangkan $\mathrm{j}$ tabel $=8$. Dari tabel nilai kritis $\mathrm{J}$ untuk uji jenjang bertanda Wilcoxon untuk $\mathrm{n}=10, \alpha=0,05$ sesuai dengan kriteria penerimaan dan penolakan hipotesis, hipotesis diterima jika $\mathbf{J}$ hitung $>\mathbf{J}$ tanel yaitu Uji $\mathbf{J}_{\text {hitung }}>\mathbf{J}_{\text {tabel }}$ dimana 15>8, dari perhitungan ini dapat dilihat pengaruh perlakuan pada kelompok ekperimen artinya pengaruh pemberian layanan penguasaan konten dengan teknik modelling lebih signifikan $(15>8)$. Ini berarti hipotesis yang berbunyi ada pengaruh signifikan pemberian penguasaan konten dengan teknik modelling terhadap meminimalisir konsep diri negatif pada siswa kelas Kelas VII SMP Nasrani 5 MedanTahun Ajaran 2017/2018dapat diterima.
\end{abstract}

Kata Kunci: Layanan Penguasaan Konten, Modeling, Konsep Diri Negatif.

\section{PENDAHULUAN}

Pendidikan sangat penting artinya, tanpa pendidikan manusia sulit berkembang dan bahkan dapat terbelakang. Dengan demikian pendidikan harus betul-betul diarahkan untuk menghasilkan manusia yang berkualitas dalam arti menguasai iptek dan mampu bersaing, berbudi pekerti luhur serta berperan aktif dalam seluruh lapangan kehidupan, cerdas intelektual, kreatif, terampil, jujur, berdisiplin dan bermoral tinggi, dan saling menghargai.
Pendidikan merupakan hal yang penting untuk semua orang, karena pendidikan dibutuhkan dalam mengarahkan anak melakukan perbuatan yang positif dan menambah pengetahuan.Untuk mencapai pendidikan yang maksimal maka sangat dibutuhkan konsep diri positif pada siswa. Proses pembentukan identitas diri dan konsep diri siswa. Proses pembentukan identitas diri dan konsep diri seseorang adalah suatu yang kompleks. Usaha individu untuk memahami dirinya sendiri kemudian menghasilkan konsep individu 
mengenai dirinya sendiri yang biasa disebut dengan konsep diri atau self concept.Salah satu penentu dalam keberhasilan perkembangan adalah konsep diri.Konsep diri (self concept) merupakan suatu bagian yangpenting dalam setiap pembicaraan tentang kepribadian manusia.Konsep diri merupakan sifat yang unik pada manusia sehingga dapat digunakan penting dalam setiap pembicaraan tentang kepribadian manusia.Konsep diri merupakan sifat yang unik pada manusia, sehingga dapat digunakan untuk membedakan manusia dari makhluk hidup lainnya.

Konsep diri seseorang dinyatakan melalui sikap dirinya yang merupakan aktualisasi orang tersebut. Manusia sebagai organisme yang memiliki dorongan untuk berkembang yang pada akhirnya menyebabkan ia sadar akan keberadaan dirinya. Perkembangan yang berlangsung tersebut kemudian membantu pembentukan konsep diri individu yang bersangkutan.

Perasaan individu bahwa ia tidak mempunyai kemampuan yang ia miliki. Padahal segala keberhasilan banyak bergantung kepada cara individu memandang kualitas kemampuan yang dimiliki. Pandangan dan sikap negatif terhadap kualitas kemampuan yang dimiliki mengakibatkan individu memandang seluruh tugas sebagai suatu hal yang sulit untuk diselesaikan, maka dari itu sangatlah penting untuk individu memahami konsep diri.

Konsep diri belum ada saat dilahirkan, tetapi dipelajari dari pengalaman unik melalui eksplorasi diri sendiri hubungan dengan orang dekat dan berarti bagi dirinya. Dipelajari melalui kontak sosial dan pengalaman berhubungan dengan orang lain. Konsep diri adalah jawaban-jawaban seseorang atas pertanyaan" siapa dirinya sebenarnya". Aspek yang paling penting dalam diri setiap individu adalah dirinya sendiri, dimana individu mengetahui apa kelebihan dan kelemahannya sendiri.

Konsep diri yang dimiliki seseorang bukan bawaan dari lahir melainkan diperoleh dari belajar atau hasil interaksi dengan orang lain dan lingkungannya. Seseorang dapat belajar dengan baik, bergaul dengan lingkunganya, penuh persahabatan dengan setiap individu, maka individu tersebut dapat memiliki konsep diri yang positif, sehingga dapat melaksanakan fungsi dan tugas dirinya dilingkungan dengan baik.Konsep diri positif dapat melaksanakan tugas dengan baik dan bertanggung jawab atas pekerjaanya.

Meskipun konsep diri tidak langsung ada begitu saat seseorang 
dilahirkan, tetapi secara bertahap seiring dengan tingkat pertumbuhan dan perkembangan seseorang, konsep diri dapat terbentuk karena pengaruh lingkunganya. Konsep diri dapat dipelajari seseorang melalui pengalamanya dengan orang lain. Hal ini akan membentuk persepsi terhadap dirinya sendiri dan penilaian persepsinya terhadap situasi tertentu.

Pengetahuan tentang konsep diri sangatlah penting, karena seringkali kesulitan atau masalah yang di hadapi oleh setiap individu dalam hidup ini sumbernya berasal dari diri sendiri dan pikiran, dimana secara berkelanjutan memberikan penilaian negatif terhadap diri sendiri dan akhirnya tidak mampu menyelesaikan persoalan yang ada, menjadi minder, kehilangan kepercayaan diri dan merasa dirinya bukanlah apa-apa, tidak berguna, tidak berpotensi, putus asa, atau bahkan sampai merasa tidak ada gunanya lagi hidup.

Berdasarkan hasil pengambilan data dan wawancara dengan guru BK yang telah peneliti lakukan di SMP Nasrani 5 Medan didapat data bahwa dari 23 siswa yang diberikan untuk mengisi angket, ada 39,2 \% siswa yang memiliki konsep diri negatif yaitu sekitar 10 orang siswa. Gejala yang terlihat pada siswa yang memiliki konsep diri negatif adalah selalu memiliki kesan yang negatif terhadap orang lain, tidak suka di kritik oleh orang lain, sangat sulit untuk mengembangkan kedekatan dengan orang lain, sangat mudah menyerah, siswa tidak memiliki rasa percaya diri, malu dengan keadaan dirinya, dan tidak mampu mengutarakan pendapatnya sehingga itu sangat berdampak negatif terhadap dirinya sendiri.

Konsep diri negatif yang dimiliki oleh individu di lingkungan sekolah SMP Nasrani 5 Medan dapat dilihat berdasarkan observasi dan pengambilan data yang dilakukan oleh peneliti disekolah tersebut. Salah satu konsep diri negatif yang dimiliki oleh siswa di SMP Nasrani 5 Medan yaitu malu dengan keadaan dirinya sendiri, misalnya Guru BK melakukan pendataan terhadap setiap kelas tentang keluarga yang kurang mampu dan individu yang kurang mampu itu akan diberikan bantuan dari pihak sekolah, tetapi siswa yang kurang mampu itu tidak ada yang berani untuk jujur mengakui tentang keberadaan dirinya sebenarnya, padahal setelah dilihat dari data-data siswa belum bayar uang sekolah dengan waktu yang sudah lama tidak membayar uang sekolah jumlahnya sangat banyak dan bahkan mereka yang tidak membayar uang sekolah selalu dipanggil ke kantor dan dibuat surat 
panggilan orang tua agar segera datang ke sekolah untuk melunaskan uang sekolah anaknya. Pada saat orang tua dari individu yang belum membayar uang sekolah itu menghadap ke sekolah sesuai dengan panggilan dari sekolah, orang tua tetap juga tidak mampu melunaskan uang sekolah anaknya dikarenakan dengan keadaan keluarga individu yang kurang mampu.

Dalam usaha pengentasan masalah konsep diri negatif diperlukan kebijakan menyeluruh yang melibatkan seluruh komponen sekolah mulai dari kepala sekolah, guru, siswa dan orang tua untuk menyadarkan dan menindaki perilaku konsep diri negatif yang dimiliki oleh setiap siswa.Kepala sekolah dituntut untuk memiliki kemampuan dalam membangun kerjasama yang harmonis dengan berbagai pihak yang terkait dengan program pendidikan disekolah seperti membuat peraturan yang tegas didalam sekolah SMP Narani 5 Medan.Salah satu layanan yang dapat diberikan oleh guru pembimbing (konselor) yaitu layanan penguasaan konten dengan teknik modeling.

Upaya yang dilakukan untuk menangani masalah pengurangan konsep diri negatif terhadap individu bisa dengan cara meningkatkan layanan bimbingan dan konseling yang dapat dilaksanakan untuk menangani permasalahan konsep diri negatif yaitu dengan penguasaan konten.

Menurut Tohirin (2007: 164) layanan penguasaan konten merupakan suatu layanan bantuan kepada individu (siswa) baik sendiri maupun dalam kelompok untuk menguasai kemampuan atau kompetensi tertentu melalui kegiatan belajar.Kemampuan atau kompetensi yang dipelajari merupakan satu unit konten yang di dalamnya terkandung fakta dan data, konsep, proses, hukum dan aturan, nilai, persepsi, afeksi, sikap, dan tindakan.

Berdasarkan pernyataan diatas layanan penguasaan konten bertujuan agar siswa menguasai aspek-aspek konten (kemampuan atau kompetensi) tertentu secara terintegrasi dan membantu individu agar tercegah dari masalahmasalah tertentu terlebih apabila kontenya terarah kepada terhindarnya individu dari masalah yang sedang dihadapi oleh individu.Dengan penguasaan konten (kemampuan atau kompetensi) oleh siswa, dapat berguna untuk menambah wawasan dan pemahaman, mengarahkan penilaian dan sikap menguasai cara-cara atau kebiasaan tertentu, untuk mampu memenuhi kebutuhanya serta mengatasi masalahmasalah yang sedang dialami oleh siswa. 
Dalam rangka pengurangan konsep diri negatif pada siswa ini salah satu layanan yang dapat diberikan adalah layanan penguasaan konten dengan teknik modeling.Layanan penguasaan konten bertujuan untuk menguasai konten atau kompetensi tertentu serta menambah pemahaman, mengarahkan tanggung jawab dan kebiasaan tertentu, memenuhi kebutuhan dan mengatasi masalahnya.Dengan menggunakan pendekatan ini dapat mengatur tugas dan kriteria yang mungkin dicapai dan individu juga dapat memeratakan sifat tanggung jawab yang dapat tercapai, tidak ada anggota yang menggantungkan diri pada rekanya yang dominan.Jadi, guru BK dapat menggunakan metode ini untuk mengurangi konsep diri negatif pada siswa.

Untuk mengatasi hal tersebut, perlu diberikan salah satu teknik dalam bimbingan dan konseling yaitu teknik modelling. Adapun teknik modelling adalah teknik yang dilakukan dengan mengamati seorang model dan kemudian diperkuat untuk mencontoh tingkah laku sang model Corey (dalam Singgih D Gunarsa 1996:221). Dengan memperagakan perilaku model, siswa dapat mengurangi konsep diri negatif pada diri individu tersebut.

\section{KAJIANPUSTAKA}

Perasaan individu bahwa ia tidak mempunyai kemampuan yang individu miliki. Padahal segala keberhasilan banyak bergantung kepada cara individu memandang kualitas kemampuan yang dimiliki. Pandangan dan sikap negatif terhadap kualitas kemampuan yang dimiliki mengakibatkan individu memandang seluruh tugas sebagai suatu hal yang sulit untuk diselesaikan, maka dari itu sangatlah penting untuk setiap individu memahami konsep diri.

Kebanyakan siswa sekarang tidak mampu mengenali dirinya sendiri siapa dirinya sebenarnya dan apa tujuan hidupnya, sesuai dengan yang peneliti melakukan wawancara dengan guru BK disekolah SMP Nasrani 5 Medan bahwa masih banyak siswa mereka yang tidak mengenali dirinya, seperti hal jika guru disekolah Nasrani 5 Medan melakukan pendataan terhadap siwa yang kurang mampu siswa dan siswa yang kurang mampu itu diberikan bantuan dari pihak sekolah maka siswa tidak ada yang mampu untuk mengakui hal itu disebabkan karena siswa merasa malu dengan dirinya sendiri, siswa merasa orang tuanya mampu untuk membiayai sekolah mereka padahal kenyataan banyak dari siswa tersebut masih banyak yang belum membayar uang sekolah 
setelah dilihat dari daftar nama yang belum membayar uang sekolah, bahkan sampai orang tua dari siswa yang belum membayar uang sekolah dipanggil kesekolah agar segera mengahadap dan melunasi uang sekolah anaknya. Ini merupakan salah satu faktor konsep diri negatif masih terdapat dalam diri individu siswa tersebut.

\section{METODE PENELITIAN}

Jenis penelitian yang digunakan oleh peneliti adalah penelitian eksperimen semu dengan pendekatan kuantitatif yaitu untuk memperoleh informasi yang merupakan perkiraan bagi informasi yang dapat diperoleh dengan eksperimen yang sebenarnya dalam keadaan yang tidak memungkinkan untuk mengontrol dan memanipulasi semua variabel yang relevan (Sutrino 2012: 18).

Desain yang digunakan dalam penelitian ini adalah pre-test - post-test Group Design yaitu dalam desain ini observasi dilakukan sebanyak 2 kali yaitu sebelum diberikan perlakuan dan sesudah diberikan perlakuan.Observasi yang dilakukan sebelum diberikan perlakuan $\left(0_{1}\right)$ disebut pre-test, dan observasi sesudah diberikan perlakuan $\left(0_{2}\right)$ disebut post-test.
Pola penelitiannya adalah sebagai berikut di bawah

\section{$\mathrm{O}_{1} \times \mathrm{O}_{2}$}

Arikunto (2006:85)

\section{Keterangan :}

$\mathrm{O}_{1}$ : Pre-test dilakukan sebelum diberikan perlakuan

$\mathrm{X}$ : Perlakuan (Layanan Penguasaan Konten Teknik Modeling)

$\mathrm{O}_{2}$ : Post-test dilakukan setelah diberikan perlakuan

Menurut Arikunto

(2006:130)

"Populasi adalah keseluruhan subjek penelitian". Apabila seseorang ingin meneliti semua elemen yang ada dalam wilayah penelitian, maka penelitianya merupakan penelitian populasi.Populasi penelitian ini adalah seluruh siswa siswi kelas VII-C SMP Nasrani 5 Medan tahun ajaran 2017/2018 yang berjumlah 22 orang.

Menurut Arikunto

(2006:131) "Sampel adalah sebagian atau wakil populasi yang diteliti. Adapun sampel penelitian yang diperoleh dari kelas VIIC berjumlah 22 orang yang diberikan angket tentang konsep diri negatif.Setelah angket dianalisis maka yang mendapat skor yang terendah yang dapat dijadikan menjadi sampel dalam penelitian ini yaitu sebanyak 10 orang.

Terdapat dua variabel yang dapat digunakan dalam penelitian ini yaitu: 
1. Variabel bebas : Layanan

penguasaan konten

teknik modellin

2. Variabel terikat : Meminimalisir

Konsep

diri

negative

Pengumpulan data dilakukan

melalui angket yang disusuan sendiri oleh peneliti berdasarkan pada aspek dengan pernyataan tertulis yang digunakan untuk memperoleh data dari responden mengenai pengurangan konsep diri negatif pada siswa dengan mengacu pada skala likert.

Untuk menguji validitas ini dilakukan dengan menggunakan teknik analisa data dan koefisien product moment yang dikemukakan oleh Arikunto (2006:170), yaitu:

$$
\begin{aligned}
& r_{x y} \\
& =\frac{N \sum X Y-\left(\sum X\right)\left(\sum \mathrm{Y}\right)}{\sqrt{\left\{N \sum X^{2}-\left(\sum \mathrm{X}\right)^{2}\right\}\left\{\mathrm{N} \sum Y^{2}-\left(\sum \mathrm{Y}\right)^{2}\right\}}}
\end{aligned}
$$

Keterangan:

rxy $=$ Koefisien korelasi

$\mathrm{x}=$ Skor responden untuk tiap item

$\mathrm{y} \quad=$ Total skor tiap responden dari seluruh item

$\Sigma \mathrm{x} \quad=$ Jumlah produk skor $\mathrm{X}$

$\Sigma \mathrm{y} \quad=$ Jumlah produk skor $\mathrm{Y}$

$\mathrm{N} \quad=$ Jumlah sampel (responden)

Dalam menganalisis data uji coba penelitian menggunakan rumus Alpha, dengan rumus sebagai berikut:

$$
r_{11}=\left[\frac{K}{(K-1)}\right]\left[1-\frac{\sum \sigma_{b}^{2}}{\sigma_{\mathrm{t}}^{2}}\right]
$$

(Arikunto, 2006:196)

\section{Keterangan :}

$\mathrm{r}_{11}=$ Reliabilitas instrumen yang dicari

$\mathrm{K}$ = Banyaknya butir pertanyaan

$\Sigma \sigma^{2} \mathrm{~b}=$ Jumlah varian butir/item

$\Sigma \mathrm{t}^{2}=$ Varians total

Untuk kriteria reliabilitas angket jika $\quad r_{\text {hitung }}>r_{\text {tabel }}$ dengan taraf signifikan $(\alpha=0,05)$ maka angket dikatakan dikatakan reliable.Namun jika $\mathrm{r}_{\text {hitung }}<$ $\mathrm{r}_{\text {tabel maka angket dianggap tidak }}$ memiliki realibilitas.

Penelitian ini dilakukan di SMP Nasrani 5 Medan yang berlokasi di jalan Turi Ujung No.108, Sudirejo I, Medan Kota, Sumatera Utara 20226.

Waktu penelitian dilakukan selama 2 bulan pada semester genap tahun ajaran 2017/2018 yang dimulai dari bulan Maret sampai dengan Mei tahun 2018.

\section{HASIL PENELITIAN DAN PEMBAHASAN}

Pada awal pelaksanaan penelitian, peneliti meminta izin kepada kepala SMP Nasrani 5 Medan untuk dapat melakukan validitas angket di sekolah tersebut.Kemudian berkonsultasi dengan guru BK SMP SMP Nasrani 5 Medan untuk melakukan validitas angket. 
Setelah itu menyebarkan angket konsep diri negatif ke kelas VII-B lalu angket konsep diri negatif diolah datanya untuk melihat pernyataan yang valid dan yang tidak valid, Setelah angket konsep diri negatifvalid dan reliabel, selanjutnya konsultasi dengan dosen pembimbing skripsi untuk langkah penelitian selanjutnya dan angket yang tidak valid tidak boleh langsung dibuang tetapi diperbaiki kalimatnya untuk dapat digunakan melakukan pre-test terhadap kelas objek. Selanjutnya peneliti meminta izin kepada kepala SMP Nasrani 5 Medan untuk dapat melakukan penelitian di sekolah tersebut.Kemudian peneliti menyebarkan angket yang sudah valid untuk mendapatkan sampel sebanyak 10 orang siswa yang memiliki konsep diri negatif di kelas VII-C SMP Nasrani 5 Medan, lalu memberikan layanan penguasaan konten teknik modelling, serta terakhir mengambil data post-test.

Sebelum dilaksanakan layanan penguasaan konten teknik modelling, konsep diri negatif siswa masih tergolong rendah.Hal ini dibuktikan dari hasil angket pre-test terhadap 22 siswa kelas VII-C. Dari hasil angket ditemukan bahwa ada 7 orang siswa berada pada kategori konsep diri negatif siswa yang rendah, 3 orang siswa berada pada kategori konsep diri negatif siswa yang sedang, dan 12 orang siswa berada pada kategori konsep diri negatif siswa yang tinggi. Hal ini menunjukkan bahwa ada sebagian siswa masih menunjukkan konsep diri negatif yang tidak baik.

Berdasarkan jumlah skor pre-test 988 dan skor post-test 1.594 maka selisih skor berjumlah 606 dengan persentase $91,86 \%$. Adapun skor tertinggi pada pretest yaitu 118 dan skor tertinggi post-test yaitu 185 maka selisih skor berjumlah 89 dengan persentase $75,42 \%$, dan skor terendah pada pre-test yaitu 86 dan skor terendah post-test yaitu 148 maka selisih skor berjumlah 31 dengan persentase $36,04 \%$. Dengan demikian maka diperoleh skor rata-rata pre-test 98,8 dan skor rata-rata post-test 159,4 maka selisih skor rata-rata 60,6 dengan persentase $61,33 \%$.

Berdasarkan dari hasil uji hipotesis terdapat pengaruh yang lebih signifikan pada kelompok ekperimen setelah diberikan perlakuan.Dari analisis data, teruji bahwa perlakuan pada kelompok ekperimen memiliki pengaruh yang lebih tinggi.Hal ini diperoleh dari perhitungan Uji $\mathrm{J}_{\text {hitung }}>\mathrm{J}_{\text {tabel }}$ dimana $15>8$, dari perhitungan ini dapat dilihat pengaruh perlakuan pada kelompok ekperimen.

Berdasarkan analisis secara keseluruhan pada 10 orang responden terjadi penurunan konsep diri negatif dan 
meningkatnya konsep diri positif, dari hasil tersebut dapat dilihat pada tes awal (pre-test) diperoleh skor rata-rata konsep diri negatif siswa 98,8 dan setelah pemberian layanan penguasaan konten teknik modeling (post-test) diperoleh $=$ 159,4 maka selisih skor rata-rata 60,6 dengan persentase $61,33 \%$, artinya ratarata skor konsep diri negatif lebih rendah sebelum mendapatkan layanan penguasaan konten teknik modeling, dan setelah diberikan layanan penguasaan konten teknik modeling maka konsep diri negatif menjadi menurun dan konsep diri positif meningkat. Namun demikian masih ditemukan responden yang memiliki perubahan yang kecil yaitu VS dan SFS, dimana hasil pre-test dari VS memperoleh skor 118 dan hasil post-test memperoleh skor 149 maka selisih skor 31 dengan persentase hanya $26,27 \%$, dan responden ke dua yaitu SFS, dimana hasil pre-test dari SFS memperoleh skor 115 dan hasil post-test memperoleh skor 154 maka selisih skor 39 dengan persentase hanya $33,91 \%$, artinya responden VS dan SFS hanya memperoleh sedikit perubahan baik sebelum dan sesudah diberikan layanan penguasaan konten dengan teknik modeling. Hal ini disebabkan bahwa VS dan SFS kurang aktif dan kurang serius selama mengikuti layanan penguasaan konten dengan teknik modeling.VS dan SFS adalah siswa yang selalu mudah menyerah dan tidak yakin cita-citanya dapat tercapai.

Hasil pada kelompok ekperimen dapat tinggi karena peneliti memberikan layanan penguasaan konten teknik modeling.Yang dimana, peneliti memberikan materi sesuai dengan indikator yang sudah ada. Selain itu, siswa juga memainkan suatu drama yang skenarionya telah dibuat sesuai dengan topik teknik modeling.

Adapun tahapan yang peneliti lakukan adalah tahap pembentukan, yang dimana peneliti mengucapkan salam, menerima secara terbuka dan mengucapkan terimakasih atas kesediaan anggota kelompok dalam mengikuti kegiatan, doa bersama, menjelaskan pengertian, tujuan, dan azaz-azaz bimbingan konseling. Tahap peralihan, yang dimana peneliti menetapkan topik yang dibahas (tugas), menanyakan kesiapan anggota kelompok. Tahap kegiatan, yang dimana peneliti melakukan tanya jawab mengenai materi atau topik yang telah ditentukan, peneliti mengatakan bahwa akan dilakukan teknik modeling untuk mencontohkan perilaku dari teori yang telah dijelaskan oleh peneliti, menjelaskan tentang teknik modeling, menentukan pemain, memberikan waktu selama 10 menit 
untuk mempelajari skenario, melaksanakan teknik modeling, memberikan kesimpulan mengenai pelaksanaan modeling, dan melakukan suatu permainan. Dan tahapan terakhir adalah tahap pengakhiran, yang dimana peneliti mengatakan bahwa kegiatan segera diakhiri, para siswa memberikan kesan dan pesan, menyepakati jadwal pertemuan selanjutnya, berdoa, bersalaman, dan menyanyikan lagu sayonara.

Pertemuan pertama topik yang dibahas hiperkritis (kurang percaya diri), materinya adalah pengertian percaya diri dan bagaimana cara untuk menumbuhkan rasa percaya diri. Pertemuan kedua topik yang dibahas mengenai individu tidak disenangi orang lain (bullying), materinya adalah pengertian bullying, penyebab bullying, dampak negatif bullying, dampak positif bullying, dan bentuk-bentuk bullying. Pertemuan ketiga yang dibahas mengenai pesimis pada kompetisi, materinya adalah pengertian pesimis, penyebab pesimis, bahaya pesimis dan cara mengatasinya. Pertemuan keempat yang dibahas mengenai respon terhadap pujian, materinya adalah pengertian memuji, cara menanggapi pujian dengan dua metode dan pertemuan kelima yang dibahas mengenai peka terhadap kritikan, materinya adalah pengertian peka dan kritikan, pengertian peka terhadap kritikan orang lain, merespon secara sehat terhadap kritikan dan alasan menunjukkan kepekaan terhadap orang lain.

Dari hasil pemberian perlakuan pada 10 orang siswa yang telah mendapatkan layanan penguasaan konten teknik modeling sebagai kelompok eksperimen dan hasil post-test peneliti mengetahui adanya perubahan pada diri siswa yang memiliki konsep diri negatif.

Observasi dilakukan dalam penelitian ini untuk mendukung hasil dari penelitian yang telah dilaksanakan dan memperkuat data post-test, hasil observasi juga menunjukkan adanya perubahan signifkan pada kelompok eksperimen yang mendapatkan layanan penguasaan konten teknik modeling. Dengan demikian salah satu usaha yang lebih efisien yang dapat dilakukan untuk mengubah konsep diri negatif siswa adalah dengan memberikan layanan penguasaan konten teknik modeling dan diperkuat dari hasil perhitungan beda non parametric Wilcoxonpada siswa yang mengikuti layanan penguasaan konten teknik modeling pada kelompok eksperimen diperoleh dari perhitungan dengan uji $\mathrm{J}_{\text {hitung }}>\mathrm{J}_{\text {tabel }} \operatorname{dimana}(15>8)$ 
yang berarti hipotesis yang diajukan dapat diterima.

Dengan demikian dapat dikatakan bahwa perubahan konsep diri negatif yang dilakukan melalui layanan penguasaan konten teknik modeling memiliki peningkatan yang lebih tinggi apabila dilihat dari semua data yang telah diperoleh.

Menurut Tohirin (2007: 164) layanan penguasaan konten merupakan suatu layanan bantuan kepada individu (siswa) baik sendiri maupun dalam kelompok untuk menguasai kemampuan atau kompetensi tertentu melalui kegiatan belajar.Kemampuan atau kompetensi yang dipelajari merupakan satu unit konten yang di dalamnya terkandung fakta dan data, konsep, proses, hukum dan aturan, nilai, persepsi, afeksi, sikap, dan tindakan.Layanan penguasaan konten bertujuan agar siswa menguasai aspekaspek konten (kemampuan atau kompetensi) tertentu secara terintegrasi dan membantu individu agar tercegah dari masalah-masalah tertentu terlebih apabila kontenya terarah kepada terhindarnya individu dari masalah yang sedang dihadapi oleh individu.Dengan penguasaan konten (kemampuan atau kompetensi) oleh siswa, dapat berguna untuk menambah wawasan dan pemahaman, mengarahkan penilaian dan sikap menguasai cara-cara atau kebiasaan tertentu, untuk mampu memenuhi kebutuhanya serta mengatasi masalahmasalah yang sedang dialami oleh siswa.

Menurut Hurlock (2002) konsep diri adalah merupakan gambaran yang dimiliki oleh seorang individu tentang dirinya sendiri yang meliputi kondisi fisik, psikologis, sosial, dan emosional, aspirasi dan prestasi

Kelompok eksperimen peneliti memberikan layanan penguasaan konten teknik modeling dengan topik tugas, dan materi sesuai dengan indikator yang telah ditentukan.Teknik modeling dapat membantu siswa untuk meminimalisir konsep diri negatif, karena siswa dapat menghayati peran secara langsung seperti betul-betul terjadi dalam situasi yang sebenarnya.

Guru BK di sekolah harus membuat dan melaksanakan program layanan penguasaan konten teknik modeling untuk siswa yang memiliki konsep diri negatif yang rendah. Karena tujuan teknik modelingpendekatan behavioristik menurut Krumboltz (dalam George 2016: 55) adalah dapat membantu memecahkan masalah siswa melalui drama, dapat mengembangkan ekspresi siswa, dapat mengayati dan menghargai perasaan orang lain. Hal-hal yang perlu diperhatikan guru BK dalam melakukan 
teknik ini adalah menentukan pemain, menjelaskan dan mengarahkan pemain, memberikan waktu 10 menit kepada pemain untuk mempelajari skenario/naskah drama, pelaksanaan teknik modeling, memberhentikan drama apabila sudah mencapai ketegangan dalam teknik modeling, mendiskusikan secara bersama hasil dari teknik modeling, memberikan kesimpulan terhadap pelaksanaan teknik modeling yang telah dilakukan oleh anggota kelompok.

\section{PENUTUP}

\section{Kesimpulan}

Berdasarkan hasil analisa data dalam penelitian ini yaitu nilai hitung = 15 dengan $\alpha=0,05$ dan $\mathrm{n}=10$, maka berdasarkan nilai kritis $\mathbf{J}$ pada uji wilcoxon $=8$. terlihat bahwa $\mathbf{J}_{\text {hitung }}>\mathbf{J}_{\text {Tabel }}$ dimana 15> 8. Artinya hipotesis diterima, ada pengaruh pemberian layanan penguasaan konten teknik modeling terhadap konsep diri negatif siswa pada kelompok eksperimen.Dengan adanya pengaruh pemberian layanan penguasaan konten teknik modelingterhadap terhadap meminimalisir konsep diri negatif siswa, maka layanan penguasaan konten teknik modeling merupakan salah satu layanan dalam BK yang mampu meminimalisir konsep diri negatif siswa.
Data pre-testpada kelompok eksperimen diperoleh rata-rata test awal (pre-test) konsep diri negatif adalah sebesar 98,8 dan test akhir (post-test) diperoleh rata-rata konsep diri negatif adalah sebesar 159,4 dengan selisih 60,6.Artinya skor rata-rata siswa setelah mendapat layanan penguasaan konten teknik modeling lebihtinggi daripada sebelum mendapat layanan penguasaan konten teknik modeling.

\section{Saran}

Adapun saran yang dikemukakan berdasarkan hasil penelitian adalah:

a. Bagi pihak sekolah disarankan agar membuat program-program bimbingan konseling salah satunya layanan penguasaan konten agar siswa lebih mengenal manfaat dari pemberian layanan penguasaan konten dengan teknik modeling

b. Bagi Guru BK di sekolah mengingat bahwa layanan penguasaan konten teknik modeling dapat meminimalisir konsep diri negatif siswa, maka selayaknya layanan penguasaan konten teknik modeling dapat digunakan dalam meminimalisir konsep diri negatif yang terjadi pada siswa di sekolah.

c. Bagi siswa diharapkan dapat meminimalisir konsep diri negatif dalam diri individu dan mengikuti 
layanan-layanan yang diberikan oleh guru pembimbing dengan sungguhsungguh.

d. Diharapkan bagi peneliti selanjutnya supaya lebih mengembangkan dan memaksimalkan pelayanan dalam berbagai layanan terkhusus layanan penguasaan konten. Berbagai layanan, diharapkan juga para guru BK di sekolah untuk dapat terus berinovasi untuk menciptakan kreasikreasi baru dalam layanan bimbingan konseling terkhusus layanan penguasaan konten

\section{DAFTAR PUSTAKA}

Abdul Rahman, A. 2013. Psikologi Sosial. Jakarta: PT Raja Grafindo Persada.

Adang Jambali, H. 2013. Psikologi Kepribadian. Bandung: CV Pustaka Setia.

Ardi Ardani, T Dkk. 2007.Psikologi Klinis. Yogyakarta: Graha Ilmu.

Arikunto, Suharsimi. 2006. Prosedur Penelitian Suatu Pendekatan Praktek. Jakarta : Rineka Cipta.

Bachri Thalib, Syamsul dkk. 2013. Psikologi Pendidikan Berbasis Analisis Empiris Aplikatif. Jakarta: Kencana Prenada Media Group.

Boeree George, C. 2016. Personality Theories. Jakarta: Prismasophie.

F Chalhoun, James dkk. 1995. Psikologi Tentang Penyesuaian dan Hubungan Kemanusiaan. Semarang: Semarang Press.
Gunarsa Singgih, D. 1996. Konseling dan Psikoterapi.Jakarta: PT BPK Gunung Mulia

Hurlock, B. Elizabeth. (2002). Psikologi Perkembangan Suatu Pendekatan Sepanjang Rentang Kehidupan.Jakarta : Erlangga

Jaenudin, U. 2013. Psikologi Kepribadian. Bandung: CV Pustaka Setia.

Kania Kurniawati, N. 2014. Komunikasi Antarpribadi. Yogyakarta: Graha Ilmu.

Prayitno. 2012. Jenis layanan dan kegiatan pendukung konseling. Padang: Universitas Negeri Padang.

Sudjana. 2005. Metoda Statistika. Bandung: PT. Tarsito Bandung.

Santrock, John W.(2007). Life-Span Development. Dubuque USA: Brown and Benchmark.

Sukitman,T. 2015. Bimbingan Konseling. Yogyakarta: DIVA Press

Sulistyarini, M. 2014. Dasar-Dasar Konseling.Jakarta : Prestasi Pustakaraya.

Sugiyono. 2015. Metode Penelitian Pendidikan. Bandung: Afabeta, CV.Badri.

Sutrisno. 2012. Metode Statistika Untuk Penelitian Kuantitatif. Ombak.

Tohirin. 2007. Bimbingan dan Konseling di Sekolah Madrasah. Jakarta: PT Raja Grafindo Persada.

Walgito Bimo. 2011. Teori-Teori Psikologi Sosial. Yogyakarta: C.V Andi offset.

Wirawan Sarwono, S. 2001. Psikologi Remaja. Jakarta: PT Raja Grafindo Persada. 
Widyastuti,Yeni. 2014. Psikologi Sosial.

Yogyakarta: Graha Ilmu.

Zan Pieter, P. 2012. Pengantar komunikasi konseling.Medan : Kencana Prenada Media Group. 